\title{
Terrorism and Multiculturalism Issues in the Frame of the Mass Media in Indonesia
}

\author{
Junaidi \\ University of Lancang Kuning, \\ Pekanbaru - Indonesia \\ drjunaidi@yahoo.com
}

\begin{abstract}
This research sought to reveal how mass media in Indonesia frame terrorism and multiculturalism issues regarded to the need of the terrorists to make use of the media to publicize their acts. The purposes of the terrorism acts vary. They might be intended to get attention, to demonstrate their ability, to demolish the government image, to scare people, or to get support for their objectives. Their acts, definitely, will not be "echoed" unless they are publicized by the mass media. Publicity is like the oxygen for the terrorists. They certainly need a stage to show off their acts and it is the publicity of the media. By using Robert N. Entman's framing model, ten news published in Kompas newspaper were analyzed. Based on the results of data analysis, it is revealed that Kompasnewspaper views terrorism as a very dangerous threat so that revising theregulations is regarded as the most feasible solution. In terms of mass media's stance, multiculturalism issues are supposed to be the appropriate concept for the pluralism of Indonesia.
\end{abstract}

Keywords-Mass Media; Terrorism; Multiculturalism

\section{INTRODUCTION}

Indonesia is known as one of the most multicultural countries in the world for its "Unity in Diversity". Indonesia consists of 17.504 islands where 11 thousands of which are inhabited by 359 tribes and 726 languages. Referring to PNPS No. 1 Year 1969 - which has been currently maintained by the Indonesian Constitutional Court - that Indonesia admits five religions. Under the leadership of K.H. Abdurrahman Wahid, (Confucianism) is declared as the sixth one. Each of the six consists of numerous conceptions in the form of social organizations. In addition, there are hundreds of dogmas grow and develop in Indonesia [1].

According to Muqoyyidin [2], when it is wellmanaged, the pluralism isa social asset which is very precious to establish a great country. Conversely, the pluralism has potentials to raise conflicts and social frictions when it is not properly organized. At this moment, Indonesia seems to be unable to manage it well especially after the fall of the Orde Baru. After this regime descended, terrorism acts take place and Islamic radicalism spreads out. In less than a decade, successive bombs rocked the pluralistic republic. The first one was Bali Bombing I, Bali Bombing II, Australian Embassy Bombing, J.W. Marriot Hotel Bombing I, J.W. Marriot Hotel Bombing II, Ritz Carlton Bombing, "Book Bomb" addressed to a number of figures, "Friday Bomb" at Mapolres mosque in Cirebon, and "Suicide Bombing" at Gereja Bethel Injil Sepenuh (GBIS) Kepunton Solo [3]. All of these cases were not spared from the mass media monitorswho tend to provide wider space of publicity to the terrorism acts in Indonesia.

The litigation toward the existence of the mass media in the activities against terrorism then emerges. An accusation called that both mass media and terrorists have similar interest. At this level, the terrorists organize and make use of the mass media strategies, on the other side; the mass media put their interest on the terrorists' activities. In this relation, terrorism could not merely be regarded as violence but also as the combination of propaganda and violence [4]. The impacts of the terrorism acts published by the mass media could raise hatred toward the terrorists. Furthermore, it is possible for the government and the mass media to work together to plan strategies to fight against the terrorism which is the crimes against peace and security of mankind [5].

The reality indicates that, when the terrorism acts take place, the mass media stand in the middle of the social realityburdenedby various interests, conflicts, complexities and numerous tricky facts. Reality results from the creation of the creative people through the power of social construction toward the world around them. The social world in this case is that defined by George Samuel in [6] as the reality which stands alone outside the individual, that according to his impression, reality "exists" in oneself and is regulated by the law. Supporting public interests is the last position of the mass media. The support is actually the vision of the mass media which has no longer been presented lately, although the slogans of the vision are still sounded.

Based on the relationship between the reality of the mass media and the news on terrorism, a research question was formulated: How does Kompas Newspaper frame the 
terrorism and multiculturalism issues in Indonesia? Consequently, this research is meant to (1) find the pattern used by Kompas Newspaper to frame terrorism issues in Indonesia, and (2) reveal the pattern of social reality construction in Kompas Newspaper.

\section{METHODOLOGY}

This research applied descriptive qualitative method. It also used framing analysis method and constructivism approach or paradigm [7] The constructivismparadigmviews that there is no reality which is objective as it is created through construction process and particular point of views [8] This research seeks to describe, to review various conditions, situations or phenomena of social reality in a community taken as the object of the research, and to draw the reality to the surface as a characteristic, model, symbol or description about a particular condition, situation or phenomenon. Hence, descriptive qualitative format is more appropriate to be used in analyzing the problems that require in-depth study such as the study of consumers' behaviors, media effects and the implementation of a policy [6]

\section{Framing}

Established the foundations for conducting framing analysis related to media content studies [9]. The framing concept proposed by Entman is used to describe the selection process and to display particular aspects of the reality [10] $\mathrm{He}$ divides framing into two major dimensions: selection issues and overemphasizing on certain aspects of the issues. It is done by selecting certain issues and ignoring the others, and displaying the aspects of the issues by using various discourse strategies, such as publishing the issues in the front or the back of the headline. The framing could appear in two levels. First, mental conception which is used to process information as the characteristics of the news items. Second, the specific materials of the news narration used to build an understanding about an event. The frame of news could be seen from the keywords, metaphors, concepts, symbols, and images presented in the news narration. Pursuant to Entman's conception, framing basically refers to providing definition, explanation, evaluation and recommendation in a discourse to emphasize specific framework of the event [11]

\section{DISCUSSION}

This section is intended to analyze how terrorism and multiculturalism issues are framed in the media. The analysis was done by using Robert N. Entman's model.

\section{Terrorism in the Frame of Media in Indonesia}

Terrorism and the mass media are closely related. In contrast to the past, the terrorists nowadays are highly dependent on the mass media to publicize their acts. The terrorism acts might have different motives such as to draw people's attention, to demonstrate their ability, to flatten the government image, to intimidate people, and to get supports for their 'struggle'. Publicity would definitely make their acts "echoed". Even the former Prime Minister of British [12] said that "Publicity is oxygen for the terrorists". They need a stage to show off their acts, and the stage is the publicity of the mass media. The Red Brigade group in Italy used to carry out terrors on Saturday in order to be published on the next day (weekly) newspapers that have greater circulation. A number of terrorism groups are known to have their own radio stations and manage their own websites [13]

\section{Map the Terrorism Basis Immediately}

On April 14 ${ }^{\text {th }}, 2016$, Kompas published news entitled "To Map the Terrorism Basis Immediately". This title and the news presented seemed to frame that the death of Siyono as an ordinary event. None of the words used in Kompas described that what was done by the Detachment of Anti-Terror 88 (Densus 88) to Siyono had violated the human rights. In contrast, the National Commission of Human Right and PP Muhammadiyah directly took concrete steps by forming an autopsy team to investigate the causes of Siyono's death in a different perspective. It was suspected that his death was due to the despotic actionsof the Densus 88 in dealing with terrorist suspects.

Kompas tends to be normative in communicating an event by taking pieces of gentle and moderate statements. This could be clearly seen from the citation it made "PP Muhammadiyahencourages the government to handle the terrorism by immediately mapping their basis". This citation then was taken as the title of thenews and became the representation of the overall news.

The essence of the news that Siyono was allegedly persecuted before he died got a very small portion in the news. The textual fact showed that "Based on the result of the autopsy done by the team formed by the National Commission of Human Right and PP Muhammadiyah, it was proved that Siyonogot persecution before he died". The Chief of BNPT, the General Commissioner Tito Karnavian was worried that the reaction of the stakeholders toward the death of Siyono could deterioratethe law enforcement. The textual fact showed that "The chief of BNPT,the General Commissioner Tito Karnavian asksSiyono's issues remains seated proportionally. The reactions coming from the stakeholders are not expected to deteriorate the law enforcement as he worries about the emergence of ideas of terminating the Densus 88". The 
statement of the chief of BNPT then was chosen by Kompas as the lead of the news. In this case, the Treatment Recommendation could be seen from the news lead "Siyono'sissues should not deteriorate the law enforcement on terrorism".

\section{Discuss the Rules Immediately}

Kompas published news on terrorism issues in which it talked about "Discussing the Rules Immediately". This news was related to the revision of law No. 15 Year 2003 about terrorism eradication. Inviting the Minister of Politics, Law and Security, LuhutBinsarPanjaitan, Kompas framed that the revision of law on terrorism was viewed urgent to prevent the terrorism acts in Indonesia. Through this news, Kompas described the importance of updating the rules so that the threat of terrorism could be prevented in accordance with the applicable laws. The news highlighting a number of people (200-300) allegedly went to Syria considered as a serious threat to national security as viewed exaggeratedly by Kompas. The issue of several citizens of Indonesia went to Syria was also associated with the Islamic State of Iraq and Syria (ISIS). The textual facts showed that "Until now, there are 200-300 citizens of Indonesia who went to Syria and join ISIS". The treatment recommendation constructed by Kompas was that the revision of law on terrorism was urgently required and became the lead of the news.

\section{Santoso Group is Continuously Hunted}

Aside from the murder of Siyono, Santoso group also got serious attention from Kompas and law enforcers related to the terrorism acts it did. Kompas published the result of its reality construction in the form of news which was still on terrorism issues. The title "Santoso Group is Continuosly Hunted" shows the way the national media like Kompas declares war against terrorism groups. The use of word "hunted" clearly indicates how media anticipate radicalism acts. Unfortunately, Kompas sometimes used terms closely related to Islam such as "mujahidin". The textual fact states "three terrorists calling themselves Mujahidin Indonesia Timur were killed". Ideally, the editorial team would remove words identical with particular ethnics, races and religions. The word "mujahidin" has positive and precious meaning in the context of Islam and it is far from radicalism. The recommendation suggested by the Entman's model to eradicate Santoso group is the termination of financial support from abroad. [14]

\section{The Densus88 is Ready to be Evaluated, and the Police} Will Conduct the Evaluation

The death of Siyono drew public attention as it seemed unreasonable so that the National Commission of Human Right and PP Muhammadiyah formed a team to do an autopsy as mentioned earlier. The news delivered is considered very normative as it makes the openness of the police to be evaluated and corrected more salience, so that it could dampen the public distrust to the police. Essentially, the death of Siyono is "sexier' than the openness of the police to be evaluated. Even though the death of Siyono could be seen as the negligence of the nation to protect its citizen who was not legally and convincingly proved to be involved in terrorism acts, the news deliveredhad built a viewpoint emphasizing more on the openness of the police than the death of Siyono. The reasons for which the openness of the police dominated the news content while the death of Siyono was disregarded, certainly, need to be explored critically.

\section{The Police Strictly Control the Entry Access into Indonesia}

In accordance to Entman's model, the treatment recommendation means that all parties have to pay attention to the return of hundreds of Indonesian citizens from Syria or those being deported from Turkey as they could potentially conduct terrorism acts. This is derived from a statement of Mbai, the former chief of BNPT, listed in the last paragraph of the news entitled "The Police Strictly Control the Access to Indonesia". He stated that "All parties need to pay attention to hundreds of Indonesian citizens coming back from Syria or those being deported from Turkey. They are highly potential to conduct terrorism acts". The statement directs people to think that Indonesian citizens coming back from Syria or those being deported from Turkey are highly potential to commit terrorism acts. This indicates that the media present the news disproportionally. In this case, the media is not sensitive toward a particular group (read Islam) because Syria and Turkey are parts of Arabian countries where most of Muslimstudentsfrom Indonesia are goingthere to study. Why should Islamic countries be framed "negative" as the house of terrorists by the mass media which then lead people to think that Islam is terrorists' religion? 


\section{Multiculturalism in the Frame of Media in Indonesia}

\section{The Pope Invites the World to Build Brotherhood}

As the top newspapers carrying the tagline "Celebrate the Diversity" and "The Mandate of the People's Conscience", Kompas commits to raise the multiculturalism issues in Indonesia. For example, Kompas puts the news entitled "Paus Invites the World to Build Brotherhood" on the first page of the newspaper on March $26^{\text {th }}, 2016$. This setting is very important and would establish people's opinion on the issues published. From the diagnosing causes, it is known that the world, currently, is torn by violence, capitalism, intolerance and inequity. Based on such conditions, the Pope invites all people to establish brotherhood and friendship. The persistence of Kompas to raise multiculturalism discourses could be seen from the moral judgment made which is, the Pope Francis denounces the violence conducted by either countries or terrorism groups. To convey his message, the Pope washed and kissed the feet of 11 refugees ( 3 of them are Muslims). By providing a viewpoint on the Pope washing the feet of three Muslims, there is a message of peace that is very remarkable in the context of multiculturalism. Furthermore, the Pope invites people to foster the sense of brotherhood by saying "Everyone, in the language of your religion, let's pray to the God that this brotherhoodcould be spread out aroundthe world". The expression "Everyone, in the language of your religion" shows how multiculturalism issues are accepted by different people and different perspectives [15].

\section{Religions Protect the Environment}

Activities of preserving environment by applying interreligious cooperation approach is an effort to raise multiculturalism issues related to social problems which are interesting to be observed. Broadening the meaning of multiculturalism in this news by raising particular issues certainly could attract public's interest on the importance of appreciating differences among citizens. The projects involving religious icons such as church and pesantren(Islamic boarding school) are kinds of interfaith and interreligious approaches. The news entitled "Religions Protect the Environment" gives equal portion for the respective viewpoint to be presented as something positive. This could be seen from the moral judgment "The Department of Society and Local Cooperation of the Ministry of Environment and Forestry has already built interreligions cooperation related to environmental preservation such as building the eco-friendly churches and pesantren". This is followedby the treatment recommendation "Interreligious approach seems to be able to preserve environment as each religion teaches people to care for their environment" accomplishing the meaning of multiculturalism.

\section{The Theology of Nationality}

Creating a new term certainly becomes one of the ways for the mass media to construct social reality of an event [16]. The theology of nationality is a new term created to bring about a spirit of upholding the importance of multiculturalism in the context of pluralistic nation. This could be seen from the news published in Kompas [17] entitled "The Theology of Nationality Needs to be Spread Out". The socio-cultural problems and the unresolved crisis faced by the nation encourage the occurrence of new term (theology of nationality). The description from the cause diagnosis becomes the key words to understand the construction of news reality "The rise of conflicts such as those taking place in Aceh Singkil and Tolikara are the concrete examples of the deterioration of the theology of nationality. The invited speakers were Sahat Martua Lumbantobing (The Head of Sekolah Tinggi Gereja Methodis Bandar Baru), Lukman Hakin Saifuddin (The Minister of Religions of Indonesia), Hasyim Muzadi (Presidential Advisory Council), and KH. Adib Rofiuddin. By using this pattern, the news lead people to realize that Indonesia is a pluralistic country for which each person has to understand one to another and committed to uphold the values of divinity and humanity.

This news seem to be 'both sides cover' which is intended to represent the viewpoints of the majority in Indonesia, but structurally, Kompas remains to give higher priority to the Christian speakercompared to other religions (Islam, Buddhist and Hindu). This could be seen from the structure of the news putting the Head of Sekolah TinggiGereja Methodis Bandar Baru in the first position (in the second paragraph), the Minister of Religion Lukman Hakim Saifuddin, Presidential Advisory Council Hasyim Muzadi, and KH. Adib Rofiuddin in the lastrow (in paragraph 6 and 7). Nevertheless, it confirms that "The theology of nationality needs to be understood and spread out. The openness of the people, mutual respect, and willingness to learn other religions from the right sources are ways to manage the socio-cultural diversities in the frame of Unity in Diversity. In addition, pesantren are expected to not only teach Islamic values but also Indonesian ones.

\section{The Dialogs Should be Started from the Grassroots Level}

In the context of nation and states, Pancasila has been etched to the life of Indonesian people. It then becomes theitem of the news entitled "Dialog Should be Started from the Grassroots Level". The importance of living in a harmony and peace under the umbrella of Unity in Diversity is the message contained in the news. It is also conveyed that the people should not give a chance to the ideology of atheism because Indonesia has the concept "there is no freedom without limits".Consequently, Indonesian citizens have to choose one of the six religions admitted. This then comes to 
the stage of Defining the Problem "The Dialog Should be Started from the Grassroots Level". To get deeper understanding, Causes Diagnosis and Moral Judgment are "Holding Interreligious Dialogs in Indonesia in the Context of Bhnineka Tunggal Ika" and "There are still different interpretations among religious communities related to the format of the dialogs in which Muhammadiyah emphasizing on theology aspects and NU focusing on humanity values". Accordingly, the recommendation is closely related to multiculturalism nuance which is "To build a harmonious life among interreligious communities in Indonesia, the dialogs between Muslim-Christian needs to be carried out from the grassroots level which is from the nearest neighborhood unit (RT/RW)".

\section{Muslim Women (Muslimat) Wants to be the Conciliators}

The commitment of Nahdlatul Ulama (NU) to convey humanity issues makes the organizations under the leadership of NU become the dealing media of Kompas Group. The news show the way the media present Indonesia in needof peace, and the peace could not be manifested if it is not established from family level. The celebration of Muslimat NU's $70^{\text {th }}$ Anniversary got serious attention from Kompas. The news entitled "Muslimat Wants to be the Conciliators" was put on page 4 . The news structure shows that the title was derived from the theme of the celebration "Getting Together to Build Peaceful and Prosperous Indonesia". Pursuant to Entman's model, the causes diagnosis of the news "The changes take place whilst and after Muktamar NU on August 2014" is the reason for which the event took such theme.The theme is certainly relevant to the condition of Indonesia which has been torn down by the disintegration issues lately. The real action done in the form ofstudy forum (pengajian), NU Muslimat always avow and give the real examples of a unity", it is also taken as the moral judgment. Meanwhile, the recommendation is that the NU Muslimat should take roles in establishing the life of the nationas theyare the agents of peace and welfare. They also build relationship through which people appreciate, accept, understand and believe one to another becomes a holistic and universal message accepted both in NU Muslimat internally and externally.

\section{CONCLUSION}

Typically, the last purpose of this research is to answer the research questions and to reachthe objectives. Based on the research findings and the results of the interpretation in the previous chapters, it is concluded that:

First, the mass media frame the terrorism issues as a violence threatening the pluralistic nation. The revision on laws is one of the ways to prevent the terrorism acts. Besides, in presenting the news, Kompas sometimes presents disproportional viewpoints in which it gives larger portion to the openness of the police to be criticized and evaluated rather than the focus to the death of Siyonodue to the despotic action done by the Densus 88 . It then imbedsparticular terminologies viewed precious and lofty in the context of Islam (mujahidin) as the terms related to terrorism activities. Furthermore, Kompas leads the people to be wary that Indonesian people coming from Syria or those being deported from Turkey are potential to commit terrorism acts in their homeland. This issue also makes people think that Syria and Turkey which are parts of Islamic Countries 'producing' terrorists.

Second, the media, especially Kompas frames the multiculturalism issues tremendously. Kompas describes the Pope washed and kissedthe feet of 11 refugees (3 of whom are Muslim). Kompas then creates new terminology "Theology of Nationality" which is intended to foster pluralism and multiculturalism in Indonesia. It is to encourage people to support the interreligious dialogs, which is the proof that Kompasis very enthusiastic to glorify pluralism and multiculturalism values in Indonesia.

\section{REFERENCES}

[1] Mubarok, H. (2010). Memahami Kembali Arti Keragaman: Dimensi Eksistensial, Sosial dan Institusional, Harmoni Jurnal Multikultural \& Multireligius, IX (35).

[2] Muqoyyidin, A. W. (2012). MembangunKesadaranInklusifmultikulturalUntukDeradik alisasiPendidikan Islam.JurnalPendidikan Islam: Vol. I, No. 2.

[3] Ma'rifah, I. (2012). Annual International Conference on Islamic Studies (AICIS) XII.Rekonstruksi Pendidikan Agama Islam: Sebuah Upaya Membangun Kesadaran Multikultural untuk Mereduksi Terorisme dan Radikalisme Islam, IAIN Sunan Ampel. 5-8 November. Surabaya: IAIN Sunan Ampel.

[4] Rakhmat, J. (1994). Psikologi Komunikasi. Bandung: PT. Remaja Rosda Karya.

[5] Kusumah, M. W. (2002). Terorisme dalam Perspektif Politik dan Hukum, Jurnal Kriminologi Indonesia FISIP UI, Vol 2 No III. 40

[6] Bungin, B. (2008). SosiologiKomunikasi (Teori, Paradigma, dan Discourse Teknologi Komunikasi di Masyarakat). Jakarta: KencanaPrenada Media Group.

[7] Creswell, J. W. (1998). Qualitatif Inquiry and Research Design. Sage Publications: California.

[8] Schwandt, T. A. (1994). Constructivist, Interpretivist Approaches to Human Inquiry. In N. K. Denzin\& Y. S. 
Lincoln (Eds.), Handbook of Qualitative Research (pp. 118- 137). Thousand Oaks, CA: Sage.

[9] Eriyanto.2001. Analisis Wacana, Pengantar Analisis Teks Media. Yogyakarta: LKiS.

[10]Entman, R. M., \&Rojecki, A. (1993).Freezing out the Public: Elite and Media Framing of the U.S. Anti-Nuclear Movement.Political Communication, 10(2), 151-167.

[11]Zaller, J. R. (1992). The Nature and Origins of Mass Opinion. Cambridge: Cambridge University Press.

[12] Tatcher, M. (1985).Speech to American Bar Association ("we must try to find ways to starve the terrorist and the hijacker of the oxygen of publicity on which they depend") - MargarethTatcher Foundation. Retrieved May 27, 2016, from http://www.margaretthatcher.org/document/106096

[13] Prajarto, N. (2004). Terorismedan Media Massa: Debat Keterlibatan Media. JurnalIlmuSosial dan IlmuPolitik.Vol 8, No L, (37 - 52).

[14]K. (n.d.).Kelompok Santoso Terus Diburu Kompas.com. Retrieved May 29, 2016, from http://print.kompas.com/baca/2016/03/01/Kelompok-

Santoso-Terus-Diburu

[15] K. (n.d.).Paus Mengajak Dunia Bangun Persaudaraan Kompas.com. Retrieved June 1, 2016, from http://print.kompas.com/baca/2016/03/26/Paus-

Mengajak-Dunia-Bangun-Persaudaraan

[16]DeFleur\& Dennis M. (1985).Understanding Mass Communication, 2nd edition. Boston: Houghton Mittlin.

[17] K. (n.d.). Teologi Kebangsaan Perlu Disebar luaskan Kompas.com. Retrieved June 2, 2016, from http://print.kompas.com/baca/2016/04/11/Teologi-

Kebangsaan-Perlu-Disebarluaskan 